Rok XV (2020) | 2 (30) | S. 149-158

https://doi.org/10.12797/LV.15.2020.30.12

Elżbieta Mańczak-Wohlfeld @

Uniwersytet Jagielloński, Kraków

manczak@uj.edu.pl

\title{
POLITYKA JĘZYKOWA W POLSCE A WPŁYW JĘZYKA ANGIELSKIEGO NA POLSZCZYZNĘ
}

Słowa klucze: polityka językowa, puryzm językowy, zapożyczenia angielskie, kontakty językowe Keywords: language policy, language purism, English borrowings, language contacts

\section{Uwagi wstępne}

Inspiracją do napisania artykułu w numerze „LingVariów” poświęconym pamięci Mirosława Skarżyńskiego była uwaga Profesora wyrażona w wywiadzie, którego udzielił w Radiu Kraków z okazji pięciolecia prowadzenia przez Niego audycji Podglądanie języka. Otóż M. Skarżyński najpierw bardzo skromnie stwierdził: „Nie czuję się ekspertem. Jestem szeregowym językoznawcą", choć z pewnością nie był przeciętnym lingwistą. We wzmiankowanym wywiadzie opowiedział się za stosunkowo liberalnym traktowaniem użycia polszczyzny, gdyż na pytanie dotyczące oceny języka ulicy powiedział: „Nie da się tego zmierzyć. Język jest, jaki jest. Nie ma języka poza nami. Mówiąc o języku, mówimy o sobie samych. Nie umiem powiedzieć, czy 38 milionów użytkowników języka mówi lepiej lub gorzej”. Wiemy jednak, że przywiązywał On dużą wagę do poprawności językowej, skoro zgodził się brać udział w audycji jej poświęconej. Celem niniejszego artykułu jest zatem przedstawienie ogólnych założeń polityki językowej i porównanie ich z praktyką stosowaną w Polsce ze szczególnym zwróceniem uwagi na wpływ angielszczyzny na polską politykę językową. 


\section{Ogólne założenia polityki językowej}

Jak wiadomo, niektórzy językoznawcy są przeciwni jakiejkolwiek interwencji w rozwój czy poprawność języka, co można skrótowo scharakteryzować tytułem klasycznej książki Roberta Halla Leave Your Language Alone! (1950) czy podobnym stwierdzeniem odnoszącym się do uprawianej w przeszłości polityki językowej w Australii, a więc tym, co określa się po francusku laisser-faire (Clyne 1991). Niemniej jednak większość lingwistów wychodzi z założenia, że ich rola jest odwrotna, żeby posłużyć się tytułem innej pracy: Do Not Leave Your Language Alone (Fishman 2006).

Wybitny językoznawca amerykański Einar Haugen, któremu oprócz licznych dokonań zawdzięczamy zainicjowanie badań nad polityką językową, uważał, że jej podstawę stanowi publikowanie słowników, gramatyk, podręczników do ortografii, aby pomóc rodzimym użytkownikom języka w jego właściwym stosowaniu. Jednak Haugen nie ograniczał się tylko do tego celu, wychodził bowiem z założenia, że polityka językowa powinna stanowić

an attempt to guide the development of a language in a direction desired by the planners. This means not only predicting the future on the basis of available knowledge concerning the past, but a deliberate effort to influence it (Haugen 1959: 8).

To przekonanie zostało później wzmocnione przez zwrócenie uwagi na powiązanie polityki językowej ze społeczeństwem, co m.in. wyrazili Björn H. Jernudd i Jyotirindra Das Gupta (1971: 211), pisząc:

We do not define planning as an idealistic and exclusively linguistic activity, but as a political and administrative activity for solving language problems in the society. Public planning, that is, orderly decision-making about language on a national level, is motivated by public effects of some language problems and by the social context.

Porównywalne podejście, a więc socjolingwistyczne, nieco później przedstawił w Polsce Władysław Lubaś (1977).

Zarówno w literaturze anglojęzycznej (np. Cooper 1989), jak i polskojęzycznej (np. Gajda 1999) spotykamy się z podobnie przedstawionymi problemami związanymi z polityką językową. Otóż wspomniani badacze uważają, że należy w niej rozróżnić dwa najważniejsze elementy. Są to: podmiot prowadzący tę politykę, czyli media, władza, rozmaite organizacje, oraz obiekt, czyli jednostki, które podlegają tej polityce.

Kolejny problem dotyczy tego, kto powinien być odpowiedzialny za politykę językową: lingwiści czy rodzimi użytkownicy języka. Niektórzy językoznawcy uważają, że rola ta przypada obu stronom. Oznacza to, że językoznawca lub przeciętny native speaker zauważa odstępstwo od normy, ocenia je pozytywnie lub negatywnie i decyduje, czy wprowadzić określoną zmianę (Neustupný 2002). Jednakże większość lingwistów twierdzi, że konieczne jest powołanie specjalnej komisji/organi- 
zacji, która czuwałaby nad poprawnością użycia języka (por. niżej przedstawione uwagi poświęcone Radzie Języka Polskiego).

Zatem w podsumowaniu przywołanych rozważań przyjmuje się, że prowadzenie polityki językowej jest konieczne wbrew wcześniej wspomnianemu twierdzeniu Roberta Halla (1950) czy Michaela Clyne’a (1991).

\section{Polityka językowa w Polsce na przestrzeni wieków}

Z oczywistych powodów na początku istnienia państwa polskiego, kiedy łacina, podobnie jak w innych krajach europejskich, była językiem Kościoła, dyplomacji, edukacji, administracji czy literatury, a język polski był używany głównie przez osoby niewykształcone, trudno mówić o jakimkolwiek zainteresowaniu polszczyzną, a tym bardziej już o prowadzeniu polityki językowej. Jak się dowiadujemy z oficjalnej strony Rady Języka Polskiego (www.rjp.pl), dopiero począwszy od XIV w. mieszkańcy Polski zdali sobie sprawę z własnej tożsamości i zaczęli się określać jako homines linguae Polonicae.

Pierwszy dowód na istnienie polityki językowej w Polsce stanowi uwaga napisana w 1440 r. przez Jakuba Parkoszowica, znanego też jako Jakub Parkosz, Jacobus Parcossius etc., profesora i rektora Akademii Krakowskiej, a zarazem autora Traktatu o ortografii polskiej. Porównał on osoby dbające o zachowanie języka i jego czystość do rycerzy broniących granic kraju. Kolejne dowody na prowadzenie pewnej polityki językowej w Polsce odnajdujemy w rozważaniach dotyczących krytyki wprowadzania do polszczyzny zapożyczeń leksykalnych. I tak już w połowie XVI w. Łukasz Górnicki w Dworzaninie polskim występuje przeciwko używaniu bohemizmów, które w owym czasie były bardzo rozpowszechnione, i proponuje zastąpienie ich neologizmami opartymi na rodzimych elementach, a także opowiada się za wskrzeszeniem archaizmów. Podobne podejście zauważamy nieco później u Grzegorza Knapiusza w odniesieniu do latynizmów. Z kolei w XVIII w. zwalczano nadużywanie galicyzmów. Nieco później, w 1817 r., Onufry Kopczyński w swej Gramatyce języka polskiego opowiedział się za napisaniem słownika polskich ekwiwalentów zapożyczeń. Mniej więcej w tym samym okresie Jan Śniadecki pisał podobnie: „Źle, zdaje mi się, sądzą ci, którzy rozumieją, że się język bogaci, kiedy do swych ubiorów przyjmują obce. Jest to owszem najkrótsza i bita droga do jego zaguby" (cyt. za: Klemensiewicz 1972: 167). Podobny pogląd wyraził inny XIX-wieczny uczony, który obawiał się, że z powodu wpływu języków obcych polski może zniknąć $\mathrm{z}$ mapy językowej. Tak purystyczne i pełne obaw nastawienie można było również zaobserwować w XX w. Zenon Klemensiewicz (1972: 169) zwraca jednak uwagę na to, że w XX w. uczeni przede wszystkim dbali o czystość oraz poprawność polszczyzny i podkreśla zasługi w tej dziedzinie takich lingwistów, jak Artur Passendorfer, Aleksander Brückner, Adam Antoni Kryński, Stanisław Szober czy Witold 
Doroszewski. Nie twierdzili oni jednak, że polski miałby zostać zastąpiony przez inny język (Mańczak-Wohlfeld 20o6).

Historycznie rzecz ujmując, po okresie zaborów i odzyskaniu niepodległości daje się zauważyć dążenie do unifikacji polszczyzny. Z tego powodu z inicjatywy Stefana Żeromskiego założono Polską Akademię Literatury, której nadrzędnym celem było dbanie o czystość języka polskiego. Natomiast w 1924 r. Sejm uchwalił ustawę stanowiącą, iż polski jest językiem urzędowym, o który z oczywistych powodów należy dbać. Konsekwencją tego miało być m.in. eliminowanie zapożyczeń rosyjskich oraz niemieckich, a więc pozostałości po okresie, kiedy Polska utraciła niepodległość, i zastępowanie ich polskimi odpowiednikami. Wiadomo, że w latach 1918-1939 na terenie Polski wśród mieszkańców dominowali Polacy. Stanowili oni niecałe 70\% ludności spośród blisko 32 milionów obywateli. Kraj był ponadto zamieszkały przez liczne mniejszości etniczne/narodowe, a więc Ukraińców, Żydów, Białorusinów, Niemców i innych, które to grupy miały jednak prawo do posługiwania się swoimi językami (https://pl.wikipedia.org/wiki/II. Rzeczpospolita\#Demografia).

Sytuacja zmieniła się po zakończeniu II wojny światowej, kiedy to w 1945 r. uchwalono, że tylko polski powinien funkcjonować na terenie kraju jako język oficjalny. Na podstawie spisu ludności przeprowadzonego przez Główny Urząd Statystyczny w 1950 r. uznać można, że w Polsce żyło wówczas ok. 25 milionów Polaków i prawdopodobnie ok. 500 tysięcy przedstawicieli mniejszości etnicznych/narodowych. Są to tylko dane szacunkowe, gdyż GUS nie przewidział zadawania w spisie pytań o pochodzenie narodowe czy etniczne. Podsumowując, można uznać, że powojenna Polska stała się krajem w zasadzie monoetnicznym poniekąd za sprawą działań wojennych i ich konsekwencji, ale także z powodu sprzeczności cechującej władze komunistyczne, które z jednej strony głosiły hasła internacjonalistyczne, ale w rzeczywistości prowadziły politykę nacjonalistyczną. Warto posłużyć się choćby przykładem czystki przeprowadzonej po roku 1968, kiedy to od wielu stanowisk odsunięto tzw. obce elementy.

Przechodząc do opisu polityki językowej w Polsce po zakończeniu II wojny światowej, możemy wyróżnić dwa okresy w jej prowadzeniu: do 1970 r. obowiązywała polityka tradycyjna, zorientowana na poprawność standardowej polszczyzny i eliminację regionalizmów, a od 1971 r. do czasów nam współczesnych obserwujemy politykę bardziej elastyczną zorientowaną na opis języka, a nie na preskryptywizm. W obu tych okresach miała miejsce, podobnie jak w przeszłości, obrona przed wpływami obcymi. W pierwszym okresie chodziło głównie o wyeliminowanie germanizmów, choć w tym czasie można było zauważyć również obecność wielu rusycyzmów nie tylko w warstwie leksykalnej, lecz także na poziomie składniowym, których z przyczyn politycznych nie zwalczano tak silnie. Warto dodać, że w drugiej połowie XX w. dodatkowo zaczyna się nasilać wpływ angielszczyzny. Z tego powodu nie należy się dziwić, że lingwiści występowali przeciwko wpływom innych języków, w tym angielskiego, na język polski (zob. np. Buttler, Kurkowska, Satkiewicz 1976; por. Kuźniak, Mańczak-Wohlfeld 2016). 


\section{Wpływ języka angielskiego na polszczyznę}

$\mathrm{Na}$ temat kontaktu angielszczyzny z językiem polskim pisałam wielokrotnie (np. Mańczak-Wohlfeld 2002, 2004, 2008a, b, 2010), więc w tym miejscu ograniczę się tylko do dwu stwierdzeń. Po pierwsze, wpływ języka angielskiego powinno się datować na okres wcześniejszy, niż się powszechnie uważa, czyli na przełom XVIII i XIX w., jakkolwiek nie można zapominać o nieco wcześniejszych nikłych kontaktach. Natomiast w XIX w. w Polsce, podobnie jak w innych krajach europejskich, wpływ ten się nasila, aby osiągnąć swój szczyt w XX w., szczególnie po zmianach politycznych w 1989 r. Po drugie, wpływ ten jest znacznie mniejszy, niż się na ogół przyjmuje, o czym świadczą liczne badania, które przeprowadziłam. Wynika z nich, że częstość użycia anglicyzmów w oparciu o dane słownikowe, historyczne, analizę języka mówionego, a także ze względu na kryterium zrozumienia tychże wyrazów oraz stosunek do nich, nie pozwala sądzić, aby wpływ języka angielskiego na polski teraz i w przyszłości był tak silny, jak się częstokroć powtarza (Mańczak-Wohlfeld 2006).

Jak wyżej wspomniano, po przemianach w 1989 r. i otwarciu się Polski na świat zachodni, w szczególności na Wielką Brytanię oraz Stany Zjednoczone, faktycznie nastąpił „zalew” anglicyzmów, które cechowała stosunkowo wysoka frekwencja. Naturalnie, część z nich była zbędna, gdyż w języku polskim istniały ich odpowiedniki. Na sklepach jubilerskich pojawiły się np. napisy gold i silver pomimo istnienia rodzimych odpowiedników: złoto i srebro. Jak wiemy, te i podobne zbędne zapożyczenia angielskie z czasem wraz ze zmniejszeniem się fascynacji kulturą anglojęzyczną, a także językiem angielskim, zniknęły.

Obecnie przyjmuje się, że w standardowej polszczyźnie występuje około 4000 angielskich zapożyczeń leksykalnych, do których należy dodać bez mała 300 zapożyczeń semantycznych (Witalisz 2007) oraz około 500 rozmaitego typu kalk (Witalisz 2015).

Warto też zwrócić uwagę na to, że w obecnej dobie wpływ angielszczyzny nie ogranicza się do warstwy leksykalnej, jest on bowiem widoczny również na innych poziomach języka. W płaszczyźnie morfologicznej dochodzi do tworzenia wyrazów w języku polskim przez dodanie angielskiego sufiksu -er, np. aborter, szpaner. Ta tendencja pojawia się również w neologizmach typu blockersi, tamersi, w których dodatkowo można zaobserwować podwojenie wykładników liczby mnogiej. Innym przykładem jest użycie patronimicznego $M c$, występującego w nazwiskach szkockich i irlandzkich, np. McŚwiat. Innego patronimicznego przedrostka $O^{\prime}$, zniekształconego do A', użyto w określeniu A’Tomek. Nawiasem mówiąc, jest to jedyny przykład nieleksykalnego wpływu angielszczyzny na polski datującego się na okres wcześniejszy niż lata 90. ubiegłego wieku. Kolejnym przykładem innowacji morfologicznej jest używanie angielskiego wyznacznika liczby mnogiej -s zamiast polskiego, np. skatersi w miejsce poprawnego skaterzy czy But-s na określenie nazwy 
firmy. Ponadto sporadycznie wprowadza się angielską końcówkę dopełniacza liczby pojedynczej 's, np. Witek's (nazwa sklepu). Wreszcie tworzy się neologizmy przez dodanie angielskich afiksów/afiksoidów, jak e-(np. e-Polska, e-adwokat, e-Biblia), -(o)holic (np. sklepoholik, herbatoholiczka, Wikipedioholik), -gate (w rodzaju Okęcie gate, Kohlgate, wódka-gate), cyber- (jak cyber-miasto, cyber-żotnierz, Cyber-Wielkopolska) (Mańczak-Wohlfeld, Witalisz 2016). Podobnie formuje się wyrazy złożone z wykorzystaniem angielskich rzeczowników, np. land, shop, show, story, top, party, burger. Innym interesującym zjawiskiem jest wprowadzenie skrótu łącznika and w postaci ' $n$ ' w celu utworzenia neologizmów typu boks'n'roll.

Warto odnotować również stosunkowo częste, w przeszłości nieznane, użycie w oficjalnym języku skróconych imion w rodzaju Radek (Sikorski). Wreszcie należy zwrócić uwagę na nadużywanie wyrazu przyjaciel, będącego niewłaściwym tłumaczeniem słowa friend, który oznacza kolegę, koleżankę, znajomą, znajomego, a więc ma inne konotacje niż pol. przyjaciel. Podobnie nadużywa się wyrazu wyrafinowa$n y$, będącego tłumaczeniem ang. sophisticated. Ponadto powinno się wspomnieć o wpływie języka angielskiego na polszczyznę w warstwie frazeologicznej, czyli o nadużywaniu zwrotu dokładnie tak, będącego odpowiednikiem ang. precisely, exactly, lub fraz w formie utartych zdań: W czym moge pomóc? / Czy mogę pomóc?, będących wiernym oddaniem ang. Can I help you?, czy wreszcie życzeń miłego dnia/ weekendu przejętych $\mathrm{z}$ angielskiego Have a nice day/weekend. Wyżej przytoczone formy świadczą nie tylko o przejmowaniu pewnych utartych zdań z angielszczyzny, lecz także o zmianie w zachowaniu, a więc o pewnym wpływie kultury anglosaskiej w szerokim tego słowa znaczeniu na obyczajowość w Polsce.

Poza tym warto podkreślić oddziaływanie języka angielskiego na polszczyznę w warstwie graficznej, co jest widoczne na szyldach w rodzaju SzlafrOK czy 4 you. W tym ostatnim wypadku wykorzystuje się homofonię for i four, co stanowi dowód na dobrą znajomość angielszczyzny przez Polaka, który wprowadził ten napis (zob. uwagi poniżej).

Wydaje się, że wyżej wymienione przykłady kontaktu języka angielskiego z polskim nie są zagrożeniem dla polszczyzny. Natomiast pewne niebezpieczeństwo stanowi z pewnością obserwowany wpływ języka angielskiego na polską składnię, gdyż jest to ingerencja w system języka. Chodzi bowiem o nietypowe dla polszczyzny tworzenie wyrazów złożonych składających się z rzeczownika w formie modyfikatora poprzedzającego drugi rzeczownik. Takie wyrazy mogą zawierać jeden element angielski, np. Gdańsk Lech Walesa Airport, hurt-land, stek chałupa, Kraków Business Park, ale nie jest to konieczne, o czym świadczą takie przykłady, jak: auto złom, auto-szkoła, Wrocław Stadion. Warto podkreślić niekonsekwencję w pisowni podanych przykładów. Innym elementem stanowiącym pewne zagrożenie dla języka polskiego jest używanie odpowiedników ang. generally, co znaczy 'ogólnie, powszechnie', poza strukturą zdania (Mańczak-Wohlfeld 2006). Wreszcie trzecim elementem, będącym potencjalnym zagrożeniem dla polszczyzny, jest używanie wykrzykników 
o proweniencji angielskiej w rodzaju: oops, wow, a jak wiadomo, uczucia powinny być oddawane w języku ojczystym.

\section{Polityka językowa wobec wpływu angielszczyzny na język polski}

Jak już o tym była mowa, $\mathrm{z}$ końcem XX w. nastąpił wzmożony wpływ angielszczyzny na język polski. Nie dziwi zatem, że spotkał się on z negatywnym odbiorem wielu polskich lingwistów. W tym okresie we Wrocławiu odbył się Kongres Kultury Języka Polskiego, podczas którego Walery Pisarek uznał, podobnie jak niegdyś J. Śniadecki, iż ten ogromny napływ anglicyzmów doprowadzi do tego, że za około sto lat język polski nie będzie istniał. Wydaje się, że badacz nie był odosobniony w takim myśleniu. Oczywiście biorąc pod uwagę liczbę rodzimych użytkowników języka polskiego żyjących w Polsce i poza jej granicami, co zamyka się liczbą bez mała 50 milionów polskich native speakerów, a więc plasuje polszczyznę w pierwszej dwudziestce najpopularniejszych języków, jeśli chodzi o liczbę ich mówców, nawet pod koniec XX w. wydawało się mało prawdopodobne, aby polski mógł być uznany za język zagrożony.

Niemniej jednak w obronie języka polskiego przed potencjalnym zagrożeniem przede wszystkim ze strony angielszczyzny, choć nie był to jedyny powód, w $1996 \mathrm{r}$. została powołana Rada Języka Polskiego przy Polskiej Akademii Nauk. Celem, który przyświecał powstaniu tego ciała, było doradzanie, opisywanie, ale nie narzucanie zachowań językowych rodzimym użytkownikom polszczyzny. Rada Języka Polskiego doprowadziła do uchwalenia w 1999 r. ustawy o języku polskim. Ideami, którymi się wówczas kierowano, były ochrona języka polskiego oraz zminimalizowanie wpływów obcych, czyli - jak wspomniano wyżej - de facto wpływu języka angielskiego, choć nie całkowite jego wyeliminowanie. Po wstąpieniu Polski do Unii Europejskiej w 2004 r. ustawa ta została doprecyzowana poprzez docenienie biligwizmu, czyli wyrażenie zgody na używanie innego języka obcego w oficjalnych kontaktach, np. w biznesie czy przy zawieraniu umów, co w praktyce najczęściej sprowadza się do posługiwania się angielszczyzną. Wyrażono wówczas także zgodę na używanie dialektów lub innych języków w sytuacjach oficjalnych, jeśli określony teren jest zamieszkały przez co najmniej 20\% użytkowników danego języka. Kolejna uchwała RJP z 2009 r. w pewnym stopniu osłabia pozycję polszczyzny, gdyż dopuszcza, aby oficjalne dokumenty, np. umowy, były napisane w dowolnym języku. Podobnie uchwała RJP z 2010 r. zezwala menedżerom banków na używanie innego języka niż polski. Naturalnie, w zdecydowanej większości wypadków chodzi o posługiwanie się językiem angielskim. Wreszcie dopuszcza ona używanie angielskiego w celach marketingowych, np. już wymieniony i skrytykowany przykład Kraków Business Park czy Szczecin Floating Arena. Powyższe inicjatywy stanowią promocję dwujęzyczności, która z pewnością w obecnej dobie jest nieunikniona. Oczywiście jest to słuszne działanie poza wypadkami, kiedy, jak już o tym była mowa, język angielski narusza system języka polskiego. 
Owa dwujęzyczność jest również widoczna na uczelniach, co wyraża się w popieraniu internacjonalizacji badań poprzez udział naukowców w międzynarodowych konferencjach czy publikowanie po angielsku, który to język po zakończeniu II wojny światowej stał się dominującym językiem nauki. Warto zwrócić uwagę na konieczność podawania słów kluczy oraz streszczeń na ogół w języku angielskim, jeśli publikacja ukazuje się po polsku (zob. np. wymogi „LingVariów”). Umiędzynarodowienie jest także widoczne w dydaktyce, żeby wspomnieć o programach Erasmus, Erasmus+ czy o dążeniu do uzyskiwania tzw. joint degree. Zachęca się również do zatrudniania na polskich uczelniach cudzoziemców, którzy nie tylko prowadzą w Polsce badania, ale także oferują kursy, w większości wypadków po angielsku. Kolejnym dowódem na internacjonalizację życia akademickiego jest wymóg ogłaszania konkursów w celu zatrudnienia nowych pracowników zarówno po polsku, jak i po angielsku. Ten sam wymóg dotyczy internetowych stron uczelni, w tym także opisów oferowanych kursów (Kuźniak, Mańczak-Wohlfeld 2016).

Wreszcie warto przedstawić nastawienie polskich lingwistów do kontaktu angielszczyzny z językiem polskim w XXI w. Otóż radykalnie się ono zmieniło, żeby przykładowo przytoczyć poglądy Ewy Kołodziejek (2008), która uważa, że kontakt polszczyzny $z$ angielskim powoduje, iż staje się ona językiem bogatszym i bardziej zglobalizowanym. Do podobnych konkluzji dochodzą Mirosław Bańko i inni (2016), którzy na podstawie przeprowadzonych badań uznali, że młodsze i/lub lepiej wykształcone pokolenie Polaków stosunkowo łatwo akceptuje wpływ angielszczyzny na wszystkich poziomach, a więc głównie w płaszczyźnie leksykalnej, który to wpływ najłatwiej zauważyć, morfologicznej, semantycznej, a nawet składniowej. Z kolei starsi i/lub gorzej wykształceni Polacy są bardziej konserwatywni z natury rzeczy i tym samym nie aprobują ,anglicyzacji” języka polskiego.

Wydaje się, że opisane tu pozytywne nastawienie do wpływu angielszczyzny, do którego w dużej mierze przyczyniły się działania Rady Języka Polskiego, zmiana stosunku językoznawców do kontaktu języka angielskiego z polskim, a także znacznie lepsza znajomość angielskiego, jaką obserwujemy wśród Polaków od 1989 r., wpisują się się w ogólny stosunek do języka angielskiego. On sam nie tylko stał się językiem komunikacji międzynarodowej, a więc językiem globalnym, ale także dawcą wielu elementów angielskich do języków używanych na całym świecie. Nie należy jednak zapominać, że w przeszłości angielski czerpał z innych języków (głównie francuskiego i łaciny), czego dowodem jest fakt, że ponad 60\% słownictwa angielskiego ma proweniencję romańską. 


\section{Literatura}

Bańko M., Svobodová D., Rączaszek-Leonardi J., Tatjewski M., 2016, Nie całkiem obce. Zapożyczenia wyrazowe w języku polskim i czeskim, Warszawa.

Buttler D., Kurkowska H., Satkiewicz H., 1976, Kultura jezyka polskiego. Zagadnienia poprawności gramatycznej, wyd. 3, Warszawa.

Clyne M., 1991, Community Languages. The Austrialian Experience, Cambridge.

Cooper R.L., 1989, Language Planning and Social Change, Cambridge.

Fishman J.A., 2006, Do Not Leave Your Language Alone: The Hidden Status Agendas within Corpus Planning in Language Policy, Mahwah.

Gajda S., 1999, Program polskiej polityki językowej (rozważania wstępne), [w:] J. Mazur (red.), Polska polityka językowa na przełomie tysiącleci, Lublin, s. 37-46.

Hall R.A., 1950, Leave Your Language Alone!, Ithaca, N.Y.

Haugen E., 1959, Planning for a Standard Language in Modern Norway, „Anthropological Linguistics" I, nr 3, s. 8-21.

Jernudd B.H., DAs Gupta J.D., 1971, Towards a Theory of Language Planning, [w:] J. Rubin, B.H. Jernudd (red.), Can Language be Planned? Sociolinguistic Theory and Practice for Developing Nations, Honolulu, s. 195-215.

Klemensiewicz Z., 1972, Historia języka polskiego, cz. 3: Doba nowopolska (od ósmego dziesięciolecia XVIII wieku do r. 1939), Warszawa.

KoŁodzIejex E., 2008, Nowa jakość polszczyzny: zagrożenie czy szansa?, [w:] Z. Cygal-Krupa (red.), Współczesna polszczyzna: stan, perspektywy, zagrożenia, Kraków - Tarnów, s. 33-40.

Kuźniak M., Mańczak-Wohlfeld E., 2016, Language Planning Activities and Policy the Case of Poland, "Glottodidactica. An International Journal of Applied Linguistics” XLIII, nr 2, s. 63-83.

Lubaś W. (red.), 1977, Polityka językowa, „Socjolingwistyka” I, Katowice.

Mańczak-Wohlfeld E., 2002, Polish, [w:] M. Görlach (red.), English in Europe, Oxford, S. 213-228.

MańCZak-Wohlfeld E., 2004, Does the Spread of English Constitute a Threat to Polish?, [w:] A. Duszak, U. Okulska (red.), Speaking from the Margin. Global English from a European Perspective, Frankfurt am Main, s. 177-188.

MańCZaK-Wohlfeld E., 2006, Angielsko-polskie kontakty językowe, Kraków.

Mańczak-Wohlfeld E., 2008a, Influences of English in Contemporary Polish, [w:] E. Andrews (red.), Linguistic Changes in Post-Communist Eastern Europe and Eurasia, „East European Monographs” 733, New York, s. 88-102.

Mańczak-Wohlfeld E., 2008b, The Impact of English on Polish: Myth or Truth?, „Kwartalnik Neofilologiczny" LX, nr 1, s. 3-8.

MańCZAK-Wohlfeld E. (red.), 2010, Słownik zapożyczeń angielskich w polszczyźnie, Warszawa.

MańcZak-Wohlfeld E., Witalisz A., 2016, The Influence of English Morphology on Polish, „Kwartalnik Neofilologiczny” LXIII, nr 4, s. 421-434.

NeustupnÝ J.V., 2002, Sociolingvistika a jazykový management, „Sociologický časopis” 38, nr 4, s. 429-442.

Witalisz A., 2007, Anglosemantyzmy w języku polskim: ze słownikiem, „Język a Komunikacja”, t. 16, Kraków. 
Witalisz A., 2015, English Loan Translations in Polish: Word-Formation Patterns, Lexicalization, Idiomaticity and Institutionalization, „Studies in Language, Culture and Society" 7, Frankfurt am Main.

https://pl.wikipedia.org/wiki/II. Rzeczpospolita\#Demografia www.rjp.pan

\section{Language Policy in Poland in the Context of the Impact of English on Polish Summary}

The paper examines the way and the extent to which language policies have affected the development of the Polish language. However, the purpose of the present paper is to highlight the change in attitude towards the increasing impact of English on Polish. The influence of English became more prominent in Poland after the change in the political system in 1989, and has for the most part been in the area of lexical borrowings. However, the influence of English is not only restricted to the inflow of English loanwords, but also extends to their relatively high frequency of usage. In addition, there is evidence of other types of influence that are non-lexical. However, the impact of English on Polish has not been as extensive as is claimed by some Polish linguists who since the early 1990 os have lamented over the decline of the Polish language caused by the "flood" of British and American English borrowings. Indeed, the status of English as a lingua franca was considered itself to be a threat to Polish, with even the possibility of the extinction of the tongue. This concern about language purity led to the creation of the Polish Language Council in 1996, whose aim has been to advise on and describe (rather than prescribe) linguistic behaviours among Polish language users. This legislative body was behind the Polish Language Act passed in 1999. Its purpose, however, has been to protect Polish rather than to purify it and to minimize the foreign influences (which mainly refer to English) rather than to eradicate them. Since the beginning of the $21^{\text {st }}$ century, the Polish linguists' attitude towards the "Anglicization" of the Polish language has changed dramatically and it is now believed that the influence of English makes Polish richer and more globalized. 